\title{
Effect of plant growth regulators on the growth and direct shoot formation from leaf explants of the hybrid Phalaenopsis 'Pink'
}

\author{
Meutia ZAHARA ${ }^{1,2}$, Avishek DATTA $^{1 *}$, Patchareeya BOONKORKAEW ${ }^{3}$, Abha MISHRA $^{4}$
}

Received June 21, 2016; accepted December 10, 2017.

Delo je prispelo 21. junija 2016, sprejeto 10. decembra 2017.

\begin{abstract}
Phalaenopsis orchids are one of the most beautiful flowering plants. The objective of this study was to identify the best plant growth regulator combination and medium for the growth and direct shoot formation from leaf explants of the hybrid Phalaenopsis 'Pink'. Leaf tips segments from in vitro young plants were cultured on half-strength Murashige and Skoog (MS) and Vacin and Went (VW) media supplemented with different concentrations of auxin $[\alpha$-napthaleneacetic acid (NAA)] and cytokinins [6-benzylaminopurine (BAP) or thidiazuron (TDZ)]. The explants that were cultured on $0 \mathrm{mg}$ $\mathrm{l}^{-1} \mathrm{NAA}$ and $3 \mathrm{mg} \mathrm{l}^{-1}$ BAP supplemented to half-strength MS medium formed shoots successfully within 10 weeks of culture with $5 \%$ regenerants and $50 \%$ survival frequency. The explants cultured on $0.5 \mathrm{mg} \mathrm{l}^{-1} \mathrm{NAA}$ and $1.5 \mathrm{mg}^{-1} \mathrm{TDZ}$ supplemented to half-strength MS medium developed calluses and shoots within 11 weeks of culture with $25 \%$ regenerants and $90 \%$ survival frequency. Future research needs to be directed to find out the shortest time of shoot regeneration to produce viable plants with a high survival frequency.
\end{abstract}

Key words: Phalaenopsis; shoot formation; $\alpha$ napthaleneacetic acid; 6-benzylaminopurine; thidiazuron
IZVLEČEK
UČINEK RASTLINSKIH RASTNIH REGULATORJEV NA RAST IN NEPOSREDNO TVORBO POGANJKOV IZ LISTNIH IZSEČKOV PRI KRIŽANCU Phalaenopsis 'Pink'

Orhideje iz rodu Phalaenopsis so med najlepšimi cvetnicami. Namen te raziskave je bil ugotoviti najprimernejšo kombinacijo rastlinskih rastnih regulatorjev in gojišč za rast in neposredno tvorbo poganjkov iz listnih izsečkov križanca Phalaenopsis 'Pink'. Izsečki vrhnjih delov lista mladih, in vitro vzgojenih rastlin so bili gojeni na polovičnem Murashige in Skoog (MS) ter Vacin in Went (VW) gojišču, in dodane so bile različne koncentracije auksina [ $\alpha$-naftalenocetna kislina (NAA)] in citokinina [6-benzilaminopurin (BAP) ali tidiazurona (TDZ)]. Izsečki, ki so bili gojeni na polovičnem MS gojišču $z$ dodatkom $0 \mathrm{mg}^{-1}$ NAA in $3 \mathrm{mg}^{-1}$ BAP so v desetih tednih uspešno tvorili poganjke s $5 \%$ nastalih regenerantov in $50 \%$ preživetjem. Izsečki, ki so bili gojeni na polovičnem MS gojišču z dodatkom $0.5 \mathrm{mg} \mathrm{l}^{-1} \mathrm{NAA}$ in $1.5 \mathrm{mg}$ $1^{-1}$ TDZ so tvorili kalus in poganjke v enajstih tednih s $25 \%$ nastalih regeneratov in $90 \%$ preživetjem. Potrebne so še nadaljnje raziskave za določitev najkrajšega časa regeneracije poganjkov, ki bi dale vitalne rastline $\mathrm{z}$ dobrim preživetjem.

Ključne besede: Phalaenopsis; tvorba poganjkov; $\alpha$ naftalenocetna kislina; 6-benzilaminopurin; tidiazuron

\footnotetext{
1 Department of Food, Agriculture and Bioresources, School of Environment, Resources and Development, Asian Institute of Technology, Pathum Thani 12120, Thailand; "Corresponding author: datta@ait.ac.th; avishek.ait@gmail.com

2 Department of Biology, Muhammadyah Aceh University, Banda Aceh 23245, Indonesia

3 Department of Horticulture, Faculty of Agriculture, Kasetsart University, 50 Ngam Wong Wan Road, Chatuchak, Bangkok 1090, Thailand

4 Asian Centre of Innovation for Sustainable Agriculture Intensification, Asian Institute of Technology, Pathum Thani 12120, Thailand
} 


\section{INTRODUCTION}

Species from the genus Phalaenopsis, Orchidaceae, also known as "moth orchids", are one of the most popular, beautiful and unique flowering plants in the world due to their large, colourful, durable flowers and their adaptability to room condition. They have a very high economic value in Europe, Asia and other continents. They are commercially grown for the production of the cut flowers and potted plants (Košir et al., 2004; Niknejad et al., 2011). Phalaenopsis orchids are distributed throughout Southeast Asia with a few species extending from Taiwan, Indian State of Sikkim to Australia and the Pacific (Teob, 1989). Phalaenopsis hybrids are the result of intensive breeding of plants for increasing market value as cut flowers and even more as potted plants. The duration and intensity of flowering depend mostly on the genotype and the breeding technology, which greatly influences the vitality of the plants. Species from the genus Phalaenopsis are difficult to propagate vegetatively as they are monopodial epiphytic orchids (Košir et al., 2004). The characteristics of seedlings propagated by ordinary vegetative means are not uniform and propagation through tissue culture has been the most desired way of propagation (Košir et al., 2004).

The main objective of tissue culture is the development of protocols to regenerate whole plants from single cells, plant cells without cell walls (protoplasts) and calluses (Chen et al., 2000). This technique is based on the principle of totipotency and has contributed a large scale to the production of plants of economic importance such as orchid and other ornamental plants. However, conventional breeding is slow and difficult as it requires almost two to three years for completing a life cycle (Niknejad et al., 2011; Purohit, 2005).

Many researchers have developed in vitro protocols for Phalaenopsis (Chen et al., 2000; Lu, 1993). Some authors also have reported frequent callus formation as an intermediate phase just prior to somatic embryogenesis or regeneration to protocorms (Ishii et al., 1998). Researchers observed the formation of embryonic callus when they used $73 \%$ of Phalaenopsis shoot-tip explants excised from flower stalk buds and by culturing for seven months on New Dogashima Medium (NDM) containing plant growth regulators (PGRs) such as auxin ( $\alpha$-napthaleneacetic acid (NAA)) and cytokinin (6-benzylaminopurine (BAP)) (Tokuhara and Mii, 2001). Leaf sections from in vitro young plants of Phalaenopsis gigantea J.J.Sm. on NDM supplemented with cytokinins such as BAP, thidiazuron (TDZ) and kinetin (KIN) alone and in combination with auxin (NAA) were cultured and the development of callus and protocorm-like-bodies (PLBs) from explants within six weeks of culture was observed (Niknejad et al., 2011). Direct regeneration without undesirable callus formation shortens the time period needed for regeneration and reduces the possibility of the occurrence of somaclonal variation (Košir et al., 2004). However, more research needs to be done to find out the best medium and PGR with the right concentration that could provide an efficient shoot formation from Phalaenopsis in short period of time (Arditi and Ernst, 1993; Park et al., 2001). The objective of this research was to identify the best PGR combination and medium for the growth and direct shoot formation of the hybrid Phalaenopsis 'Pink' from leaf explants.

\section{MATERIALS AND METHODS}

\subsection{Plants material and culture conditions}

Laboratory experiments were carried out during March to August 2014 at plant tissue culture laboratory, Rapee Sagarik Orchid Garden, Department of Horticulture, Faculty of Agriculture, Kasetsart University, Thailand. Three months old in vitro young plantlets of hybrid orchid (Phalenopsis 'Pink') purchased from the Salaya Orchid Company in Nonthaburi, Thailand were used as donor plants. Flower stalk explants were used to produce donor plants that were cultured on Vacin and Went (VW) medium supplemented with $10 \mathrm{~g} \mathrm{l}^{-1}$ sucrose, $15 \mathrm{~g} \mathrm{l}^{-1}$ banana extract and $15 \mathrm{~g} \mathrm{l}^{-1}$ potato extract for regeneration and multiplication (Zahara et al., 2016).
In this study, half-strength Murashige and Skoog (MS) medium (Murashige and Skoog, 1962) and VW medium (Vacin and Went, 1949) were used as the basal medium for the growth and direct shoot formation. Leaf tips segments from donor plants were cut about $1 \mathrm{~cm}$ in diameter, and placed on half-strength MS or VW medium containing two NAA concentrations $(0$ and 0.5 $\mathrm{mg} \mathrm{l}^{-1}$ ) supplemented with either five concentrations of $\operatorname{BAP}\left(0,1,2,3\right.$ and $\left.4 \mathrm{mg} \mathrm{l}^{-1}\right)$ or five concentrations of TDZ $\left(0,0.5,1,1.5\right.$ and $\left.2 \mathrm{mg}^{-1}\right)$. The $\mathrm{pH}$ of the medium was adjusted to 5.6 for MS medium and 5.2 for VW medium with $1 \mathrm{~mol} \mathrm{KOH}$ or $1 \mathrm{~mol} \mathrm{HCl}$ prior to autoclaving for 15 minutes at $121{ }^{\circ} \mathrm{C}$. The media were placed in sterile vials $(25 \mathrm{ml})$ prior to autoclaving. Subsequently, all explants were placed onto the surface of either half-strength MS or VW medium for five 
months and kept in a culture room at $25{ }^{\circ} \mathrm{C}$ during the light and dark phase in a 15 -h photoperiod under the light intensity of $40 \mu \mathrm{mol} \mathrm{m} \mathrm{m}^{-2} \mathrm{~s}^{-1}$ provided by cool white florescent tubes. Subculture was done in every 21 days onto the same PGR combination and medium.

\subsection{Induction of direct shoot regeneration}

Leaf explants $(1 \mathrm{~cm} \times 1 \mathrm{~cm})$ were used to test the effects of NAA $\left(0\right.$ and $\left.0.5 \mathrm{mg} \mathrm{l}^{-1}\right)$ with different concentrations of $\operatorname{BAP}\left(0,1,2,3\right.$ and $\left.4 \mathrm{mg} \mathrm{l}^{-1}\right)$ or $\operatorname{TDZ}(0,0.5,1,1.5$ and $2 \mathrm{mg} \mathrm{l}^{-1}$ ) supplemented to half-strength MS or VW medium on the growth and direct shoot formation. A total of 10 vials each with two leaf explants were used in each treatment combination. Data were recorded after five months of culture.

\subsection{Experimental design and data analysis}

The vials were arranged in a completely randomized design with 20 replications per treatment. Each experimental treatment combination consists of two factors: NAA concentrations and different concentrations of BAP or TDZ in either half-strength MS or VW medium. In vitro growth was evaluated 150 days after cultures were initiated. The parameters recorded were leaf length, leaf width, percentage of regenerants and survival frequency of explants. The data were subjected to analysis of variance (ANOVA) and significant differences among the treatments were tested using two-way ANOVA and means were separated by Duncan multiple range test (DMRT) at $\mathrm{p} \leq 0.05$ using SAS 9.1.3 (SAS Institute, Cary, NC, USA).

\section{RESULTS}

\subsection{Effects of NAA and BAP supplemented to half- strength MS medium on the growth and direct shoot formation of leaf explants}

The combination of NAA and BAP supplemented to half-strength MS medium significantly affected the growth and direct shoot formation of leaf explants (Table 1). After five months of culture, most of the leaf explants showed an increase in leaf length and survival frequency with increasing BAP concentration, regardless of NAA concentration. However, leaf width did not significantly change in most of the explants. Leaf length was the highest $(2.43 \pm 0.01 \mathrm{~cm})$ at $0 \mathrm{mg} \mathrm{l}^{-1}$ NAA in combination with $4 \mathrm{mg} \mathrm{l}^{-1}$ BAP with $50 \%$ survival rate. Leaf width of the hybrid Phalaenopsis 'Pink' did not increase when cultured on NAA and BAP supplemented to half-strength MS medium as it was similar in all concentrations of NAA and BAP, except for the concentrations of $0.5 \mathrm{mg}^{-1} \mathrm{NAA}$ with 2, 3 and 4 $\mathrm{mg} \mathrm{l}^{-1}$ BAP where leaf width was comparatively smaller. Somatic embryos were formed directly from the cut edge/wounding area (5\%) at $0 \mathrm{mg} \mathrm{l}^{-1} \mathrm{NAA}$ and $3 \mathrm{mg} \mathrm{l}^{-1}$ BAP combination culture with $50 \%$ survival rate (Figs. 1a \& 2). Shoots also directly formed at 0.5 $\mathrm{mg} \mathrm{l}^{-1}$ NAA and $2 \mathrm{mg} \mathrm{l}^{-1}$ BAP within $10-11$ weeks of culture with $40 \%$ survival frequency. Overall, the combination of $0 \mathrm{mg} \mathrm{l}^{-1} \mathrm{NAA}$ and $3 \mathrm{mg} \mathrm{l}^{-1}$ BAP supplemented to half-strength MS medium showed optimal growth and direct shoot formation from leaf explants of the hybrid Phalaenopsis 'Pink' (Fig. 2). 
Meutia ZAHARA et al.

Table 1: Effects of NAA and BAP supplemented to half-strength MS medium on leaf formation, percentage of regenerants and survival frequency of the hybrid Phalaenopsis 'Pink' leaf explants after five months of culture

\begin{tabular}{|c|c|c|c|c|c|}
\hline $\begin{array}{l}\text { NAA } \\
\left(\mathrm{mg} \mathrm{l}^{-1}\right)\end{array}$ & $\begin{array}{l}\text { BAP } \\
\left(\mathrm{mg} \mathrm{l}^{-1}\right)\end{array}$ & Leaf length $(\mathrm{cm})$ & Leaf width $(\mathrm{cm})$ & Regenerants (\%) & Survival frequency $(\%)$ \\
\hline 0 & 0 & $2.11 \pm 0.009 \mathrm{def}$ & $1.20 \pm 0.02 \mathrm{a}$ & $0.00 \pm 0.00 \mathrm{~b}$ & $25.04 \pm 0.14 \mathrm{~d}$ \\
\hline 0 & 1 & $2.21 \pm 0.01 \mathrm{bcde}$ & $1.21 \pm 0.01 \mathrm{a}$ & $0.00 \pm 0.00 \mathrm{~b}$ & $30.20 \pm 0.29 \mathrm{c}$ \\
\hline 0 & 2 & $2.23 \pm 0.01 \mathrm{bcd}$ & $1.23 \pm 0.003 \mathrm{a}$ & $0.00 \pm 0.00 \mathrm{~b}$ & $30.70 \pm 0.19 \mathrm{c}$ \\
\hline 0 & 3 & $2.26 \pm 0.01 \mathrm{bc}$ & $1.23 \pm 0.006 \mathrm{a}$ & $5.00 \pm 0.00 \mathrm{a}$ & $50.00 \pm 0.31 \mathrm{a}$ \\
\hline 0 & 4 & $2.43 \pm 0.01 \mathrm{a}$ & $1.26 \pm 0.01 \mathrm{a}$ & $0.00 \pm 0.00 \mathrm{~b}$ & $50.60 \pm 0.26 \mathrm{a}$ \\
\hline 0.5 & 0 & $1.00 \pm 0.00 \mathrm{~g}$ & $1.21 \pm 0.01 \mathrm{a}$ & $0.00 \pm 0.00 \mathrm{~b}$ & $10.00 \pm 0.14 \mathrm{e}$ \\
\hline 0.5 & 1 & $2.06 \pm 0.01 \mathrm{f}$ & $1.20 \pm 0.00 \mathrm{a}$ & $0.00 \pm 0.00 \mathrm{~b}$ & $30.00 \pm 0.28 \mathrm{c}$ \\
\hline 0.5 & 2 & $2.10 \pm 0.07$ ef & $1.00 \pm 0.00 \mathrm{~b}$ & $5.00 \pm 0.00 \mathrm{a}$ & $40.00 \pm 0.14 b$ \\
\hline 0.5 & 3 & $2.15 \pm 0.03 \mathrm{cdef}$ & $1.00 \pm 0.00 \mathrm{~b}$ & $0.00 \pm 0.00 \mathrm{~b}$ & $40.00 \pm 0.14 b$ \\
\hline 0.5 & 4 & $2.28 \pm 0.01 \mathrm{~b}$ & $1.00 \pm 0.00 \mathrm{~b}$ & $0.00 \pm 0.00 \mathrm{~b}$ & $40.00 \pm 0.00 \mathrm{~b}$ \\
\hline$F$ & & $* * *$ & $* * *$ & $*$ & $* * *$ \\
\hline
\end{tabular}

Data are means \pm standard error (SE) of 20 replicates. Means followed by the same letter in each column do not differ by Duncan's multiple range test at $\mathrm{p} \leq 0.05$. $*$ and $* * *$ indicate significance at $\mathrm{p} \leq 0.05$ and $\mathrm{p} \leq 0.001$, respectively. 


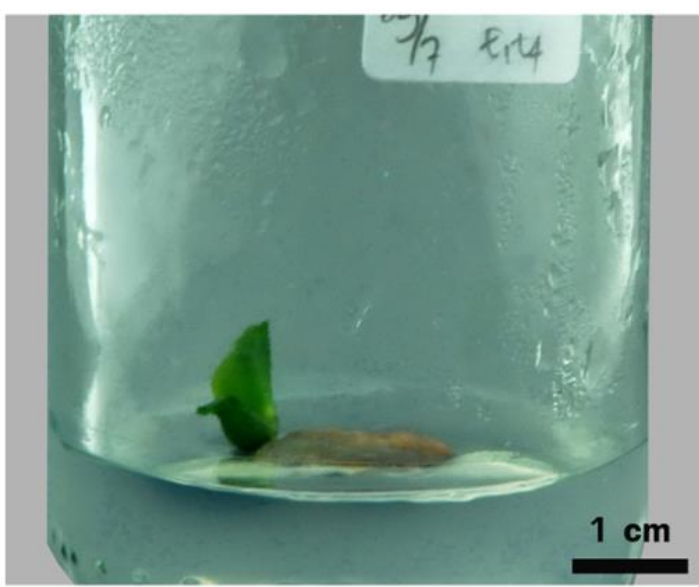

A

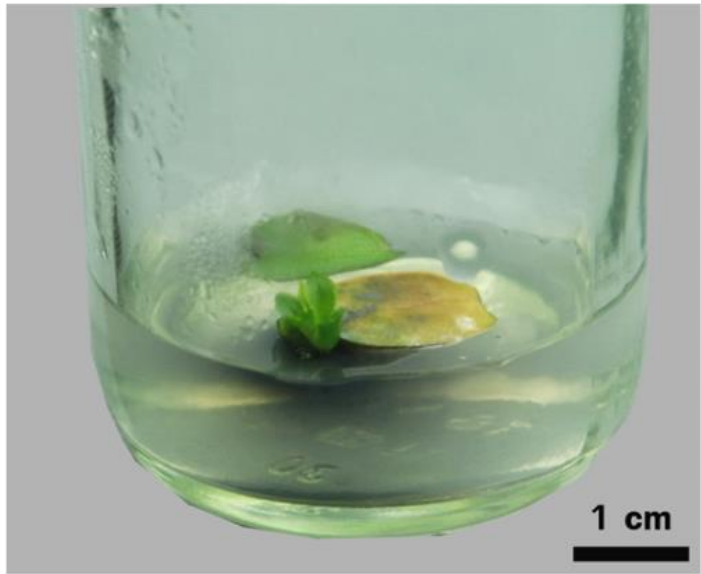

C

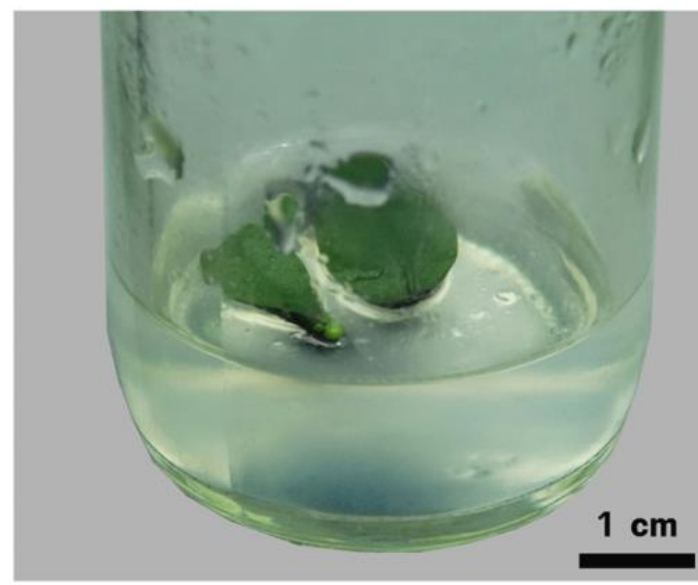

B

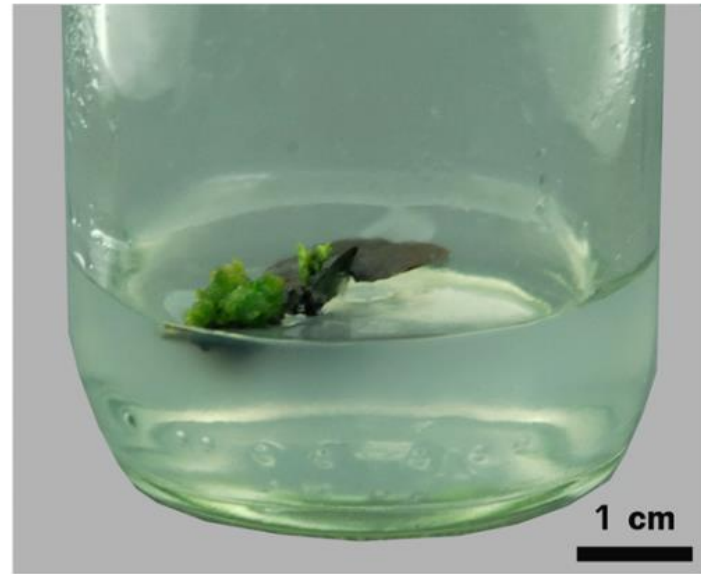

D

Figure 1: Effect of plant growth regulators on the growth and direct shoot formation from leaf explants of the hybrid Phalaenopsis 'Pink': A - Shoot formation at $0 \mathrm{mg} \mathrm{l^{-1 }} \mathrm{NAA}+3 \mathrm{mg} \mathrm{l}^{-1}$ BAP supplemented to half-strength MS medium, B - Callus formation at $0 \mathrm{mg} \mathrm{l}^{-1} \mathrm{NAA}+1 \mathrm{mg} \mathrm{l}^{-1}$ BAP supplemented to VW medium, C - Shoot formation at $0 \mathrm{mg} \mathrm{l}^{-1} \mathrm{NAA}+2 \mathrm{mg} \mathrm{l}^{-1} \mathrm{TDZ}$ supplemented to half-strength MS medium, D - Callus formation at 0.5 $\mathrm{mg} \mathrm{l}^{-1} \mathrm{NAA}+1.5 \mathrm{mg} \mathrm{l}^{-1} \mathrm{TDZ}$ supplemented to half-strength VW medium 


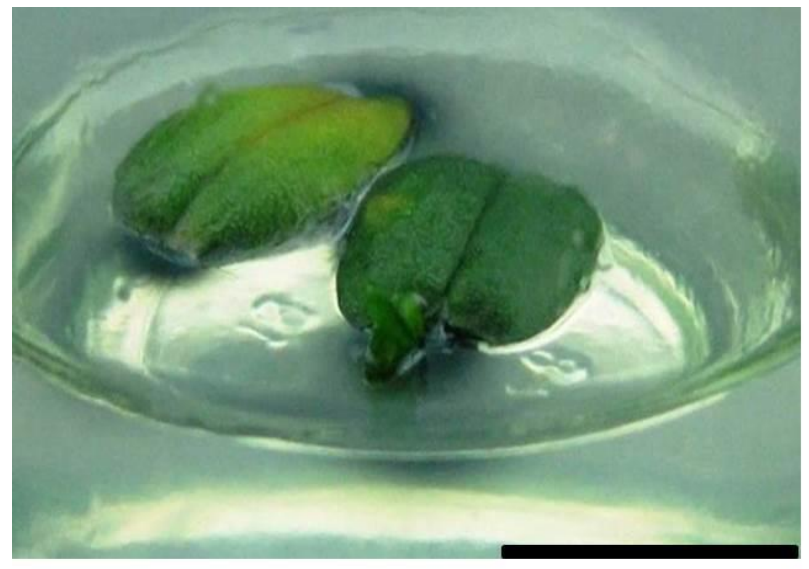

A

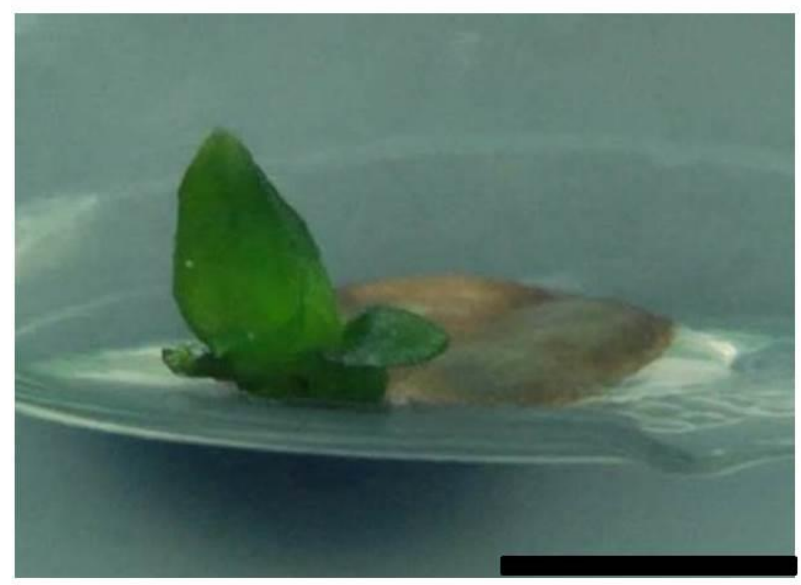

$\mathrm{C}$

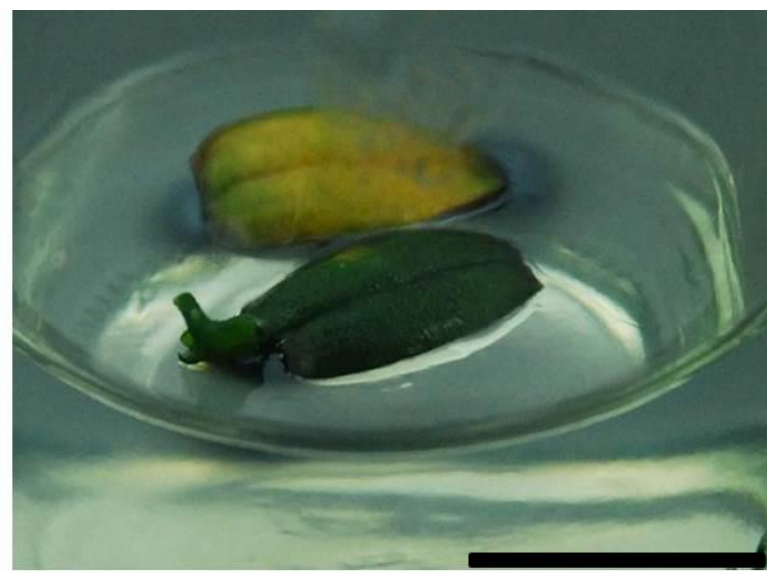

B

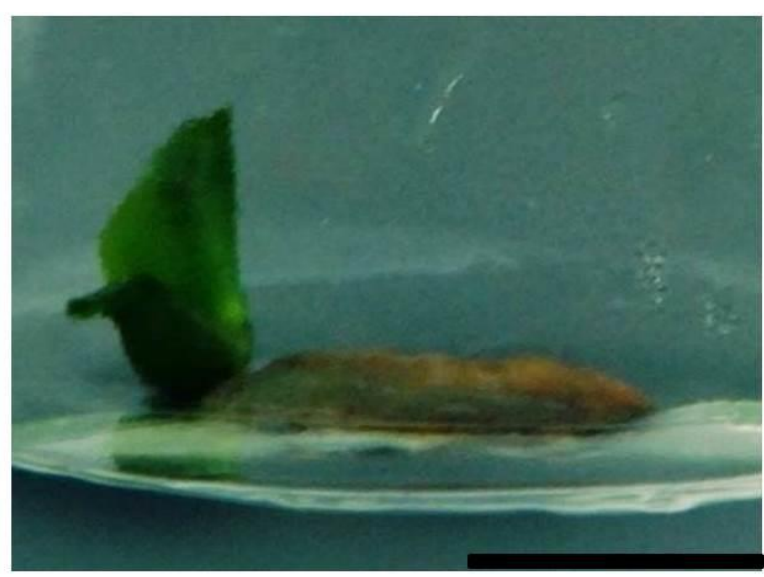

$\mathrm{D}$

Figure 2: Direct shoot formation from leaf explants of the hybrid Phalaenopsis 'Pink' without callus-mediated at 0 $\mathrm{mg} \mathrm{l}^{-1} \mathrm{NAA}+3 \mathrm{mg} \mathrm{l}^{-1}$ BAP supplemented to half-strength MS medium: A - Shoot formation after 10 weeks of culture, B - Shoot formation after 15 weeks of culture, C and D - Shoot formation after 20 weeks of culture (bar = $1.0 \mathrm{~cm})$

\subsection{Effects of NAA and BAP supplemented to VW medium on the growth and direct shoot formation of leaf explants}

Explants growth in terms of leaf length and leaf width was significantly affected by the combination of NAA and BAP supplemented to VW medium (Table 2). After five months of culture, leaf length and survival frequency showed increasing trend with increasing NAA and BAP concentration. In contrast, leaf width decreased with increasing BAP concentration regardless of NAA concentration. The combination of $0.5 \mathrm{mg} \mathrm{l}^{-1}$ $\mathrm{NAA}$ and $3 \mathrm{mg} \mathrm{l}^{-1}$ BAP resulted in the maximum leaf length $(2.66 \pm 0.02 \mathrm{~cm})$. Leaf width was showed to be optimal in the combination of $0 \mathrm{mg} \mathrm{l}^{-1} \mathrm{NAA}$ with 0 and $1 \mathrm{mg} \mathrm{l}^{-1}$ BAP as well as in the combination of $0.5 \mathrm{mg} \mathrm{l}^{-1}$ NAA with $0 \mathrm{mg}^{-1}$ BAP. Callus was directly formed in the combination of $0 \mathrm{mg} \mathrm{l}^{-1} \mathrm{NAA}$ and $1 \mathrm{mg} \mathrm{l}^{-1} \mathrm{BAP}$ from the cut edge after 15 weeks of culture and it maintained the same size until 20 weeks of growth (5 months) (Fig. 1b). Overall, the combination of $0 \mathrm{mg} \mathrm{l}^{-1}$ $\mathrm{NAA}$ and $1 \mathrm{mg} \mathrm{l}^{-1}$ BAP supplemented to VW medium showed optimal growth and direct shoot formation from the hybrid Phalaenopsis 'Pink' leaf explants. 
Table 2: Effects of NAA and BAP supplemented to VW medium on leaf formation, percentage of regenerants and survival frequency of the hybrid Phalaenopsis 'Pink' leaf explants after five months of culture

\begin{tabular}{|c|c|c|c|c|c|}
\hline $\begin{array}{l}\text { NAA } \\
\left(\mathrm{mg} \mathrm{l}^{-1}\right)\end{array}$ & $\begin{array}{l}\text { BAP } \\
\left(\mathrm{mg} \mathrm{l}^{-1}\right)\end{array}$ & Leaf length $(\mathrm{cm})$ & Leaf width $(\mathrm{cm})$ & Regenerants (\%) & Survival frequency $(\%)$ \\
\hline 0 & 0 & $2.00 \pm 0.01 \mathrm{~d}$ & $1.30 \pm 0.008 \mathrm{ab}$ & $0.00 \pm 0.00 \mathrm{~b}$ & $30.00 \pm 0.20 \mathrm{c}$ \\
\hline 0 & 1 & $2.01 \pm 0.01 \mathrm{~d}$ & $1.27 \pm 0.006 \mathrm{ab}$ & $5.00 \pm 0.00 \mathrm{a}$ & $40.00 \pm 0.31 b$ \\
\hline 0 & 2 & $2.17 \pm 0.02 \mathrm{bcd}$ & $1.25 \pm 0.006 \mathrm{bc}$ & $0.00 \pm 0.00 \mathrm{~b}$ & $40.00 \pm 0.14 b$ \\
\hline 0 & 3 & $2.18 \pm 0.01 \mathrm{bcd}$ & $1.25 \pm 0.006 \mathrm{bc}$ & $0.00 \pm 0.00 \mathrm{~b}$ & $40.00 \pm 0.20 \mathrm{~b}$ \\
\hline 0 & 4 & $2.22 \pm 0.01 \mathrm{bc}$ & $1.19 \pm 0.004 \mathrm{c}$ & $0.00 \pm 0.00 \mathrm{~b}$ & $50.00 \pm 0.14 \mathrm{a}$ \\
\hline 0.5 & 0 & $1.54 \pm 0.02 \mathrm{e}$ & $1.32 \pm 0.01 \mathrm{a}$ & $0.00 \pm 0.00 \mathrm{~b}$ & $20.00 \pm 0.14 \mathrm{~d}$ \\
\hline 0.5 & 1 & $1.68 \pm 0.07 \mathrm{e}$ & $1.00 \pm 0.00 \mathrm{~d}$ & $0.00 \pm 0.00 \mathrm{~b}$ & $30.00 \pm 0.14 \mathrm{c}$ \\
\hline 0.5 & 2 & $2.13 \pm 0.01 \mathrm{~cd}$ & $1.00 \pm 0.00 \mathrm{~d}$ & $0.00 \pm 0.00 \mathrm{~b}$ & $40.00 \pm 0.31 b$ \\
\hline 0.5 & 3 & $2.66 \pm 0.02 \mathrm{a}$ & $1.00 \pm 0.00 \mathrm{~d}$ & $0.00 \pm 0.00 \mathrm{~b}$ & $40.00 \pm 0.14 b$ \\
\hline 0.5 & 4 & $2.30 \pm 0.01 \mathrm{~b}$ & $1.00 \pm 0.00 \mathrm{~d}$ & $0.00 \pm 0.00 \mathrm{~b}$ & $50.00 \pm 0.20 \mathrm{a}$ \\
\hline$F$ & & $* * *$ & $* * *$ & * & $* * *$ \\
\hline
\end{tabular}

Data are means \pm standard error (SE) of 20 replicates. Means followed by the same letter in each column do not differ by Duncan's multiple range test at $\mathrm{p} \leq 0.05$. ${ }^{*}$ and $* * *$ indicate significance at $\mathrm{p} \leq 0.05$ and $\mathrm{p} \leq 0.001$, respectively.

\subsection{Effects of NAA and TDZ supplemented to half- strength MS medium on the growth and direct shoot formation of leaf explants}

In this experiment, the combination of NAA and TDZ supplemented to half-strength MS medium showed significant effect on the growth and direct shoot formation of leaf explants (Table 3). After five months of culture, higher concentration of NAA and TDZ resulted in greater leaf length, leaf width and percentage of survival frequency. Callus and shoots were directly formed from the leaf surface (adaxial leaf surface) and the cut edge region after 8-11 weeks of culture, respectively (Figs. 1 c, $3 \& 4)$. Leaf length $(2.63 \pm 0.008$ $\mathrm{cm})$ and leaf width $(1.31 \pm 0.004 \mathrm{~cm})$ was found to be optimal in the combination of $0 \mathrm{mg} \mathrm{l}^{-1} \mathrm{NAA}$ and $2 \mathrm{mg} \mathrm{l}^{-}$
${ }^{1}$ TDZ with $10 \%$ regenerants and $60 \%$ survival frequency. Shoots were directly formed after 8 weeks of culture in the combination of $0 \mathrm{mg} \mathrm{l}^{-1} \mathrm{NAA}$ and $2 \mathrm{mg} \mathrm{l}^{-1}$ TDZ (Fig. 3). The combinations of $0 \mathrm{mg} \mathrm{l}^{-1} \mathrm{NAA}$ and 1 $\mathrm{mg} \mathrm{l}^{-1} \mathrm{TDZ}$ as well as $0.5 \mathrm{mg} \mathrm{l}^{-1} \mathrm{NAA}$ and $2 \mathrm{mg} \mathrm{l}^{-1}$ TDZ also resulted in $5 \%$ regenerants within 11 weeks of culture. The highest frequency of regenerants $(25 \%)$ was obtained in the presence of $0.5 \mathrm{mg} \mathrm{l}^{-1} \mathrm{NAA}$ and 1.5 $\mathrm{mg} \mathrm{1^{-1 }}$ TDZ within 11 weeks of culture with $90 \%$ survival frequency (Table 3), and most of the explants formed callus (Fig. 4). Overall, the combination of 0.5 $\mathrm{mg} \mathrm{l}^{-1} \mathrm{NAA}$ and $1.5 \mathrm{mg}^{-1}$ TDZ supplemented to halfstrength MS medium showed good results across the greatest number of recorded parameters for the growth and direct shoot formation of leaf explants. 
Meutia ZAHARA et al.

Table 3: Effects of NAA and TDZ supplemented to half-strength MS medium on leaf formation, percentage of regenerants and survival frequency of the hybrid Phalaenopsis 'Pink' leaf explants after five months of culture

\begin{tabular}{llllll}
\hline NAA & TDZ & Leaf length $(\mathrm{cm})$ & Leaf width $(\mathrm{cm})$ & Regenerants $(\%)$ & Survival frequency \\
$\left(\mathrm{mg} \mathrm{l}^{-1}\right)$ & $\left(\mathrm{mg}^{-1}\right)$ & & & $(\%)$ \\
\hline 0 & 0 & $2.21 \pm 0.01 \mathrm{~d}$ & $1.00 \pm 0.00 \mathrm{~d}$ & $0.00 \pm 0.00 \mathrm{~d}$ & $40.00 \pm 0.31 \mathrm{f}$ \\
0 & 0.5 & $2.38 \pm 0.007 \mathrm{c}$ & $1.00 \pm 0.00 \mathrm{~d}$ & $0.00 \pm 0.00 \mathrm{~d}$ & $40.00 \pm 0.31 \mathrm{f}$ \\
0 & 1 & $2.40 \pm 0.008 \mathrm{c}$ & $1.00 \pm 0.00 \mathrm{~d}$ & $5.00 \pm 0.14 \mathrm{c}$ & $50.00 \pm 0.31 \mathrm{e}$ \\
0 & 1.5 & $2.60 \pm 0.01 \mathrm{ab}$ & $1.22 \pm 0.008 \mathrm{~b}$ & $0.00 \pm 0.00 \mathrm{~d}$ & $50.00 \pm 0.14 \mathrm{e}$ \\
0 & 2 & $2.63 \pm 0.008 \mathrm{a}$ & $1.31 \pm 0.004 \mathrm{a}$ & $10.00 \pm 0.14 \mathrm{~b}$ & $60.00 \pm 0.24 \mathrm{~d}$ \\
& & & & & \\
0.5 & 0 & $2.40 \pm 0.008 \mathrm{c}$ & $1.15 \pm 0.01 \mathrm{c}$ & $0.00 \pm 0.00 \mathrm{~d}$ & $50.00 \pm 0.14 \mathrm{e}$ \\
0.5 & 0.5 & $2.41 \pm 0.005 \mathrm{c}$ & $1.21 \pm 0.005 \mathrm{~b}$ & $0.00 \pm 0.00 \mathrm{~d}$ & $70.00 \pm 0.31 \mathrm{c}$ \\
0.5 & 1 & $2.42 \pm 0.007 \mathrm{c}$ & $1.22 \pm 0.004 \mathrm{~b}$ & $0.00 \pm 0.00 \mathrm{~d}$ & $80.00 \pm 0.20 \mathrm{~b}$ \\
0.5 & 1.5 & $2.58 \pm 0.005 \mathrm{ab}$ & $1.25 \pm 0.003 \mathrm{~b}$ & $25.10 \pm 0.13 \mathrm{a}$ & $90.00 \pm 0.14 \mathrm{a}$ \\
0.5 & 2 & $2.52 \pm 0.007 \mathrm{~b}$ & $1.21 \pm 0.003 \mathrm{~b}$ & $5.00 \pm 0.20 \mathrm{c}$ & $90.00 \pm 0.14 \mathrm{a}$ \\
$F$ & & $* * *$ & $* * *$ & $* * *$ & $* * *$
\end{tabular}

Data are means \pm standard error (SE) of 20 replicates. Means followed by the same letter in each column do not differ by Duncan's multiple range test at $\mathrm{p} \leq 0.05$. *** indicates significance at $\mathrm{p} \leq 0.001$. 


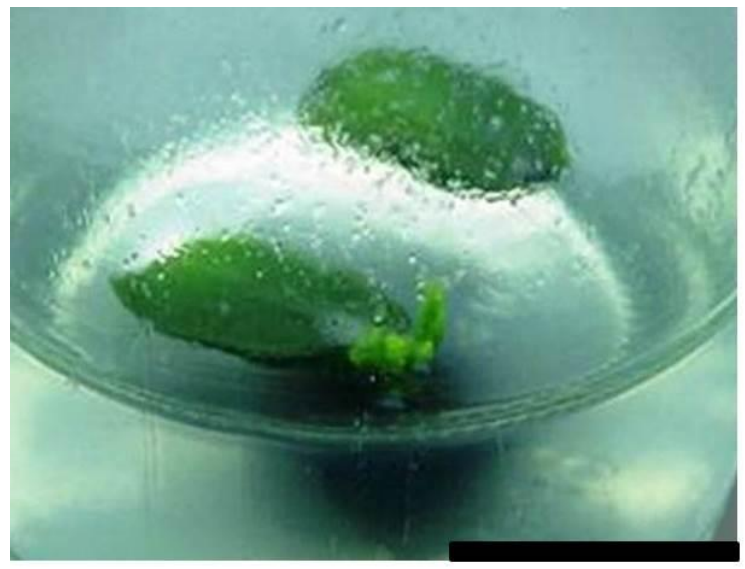

A

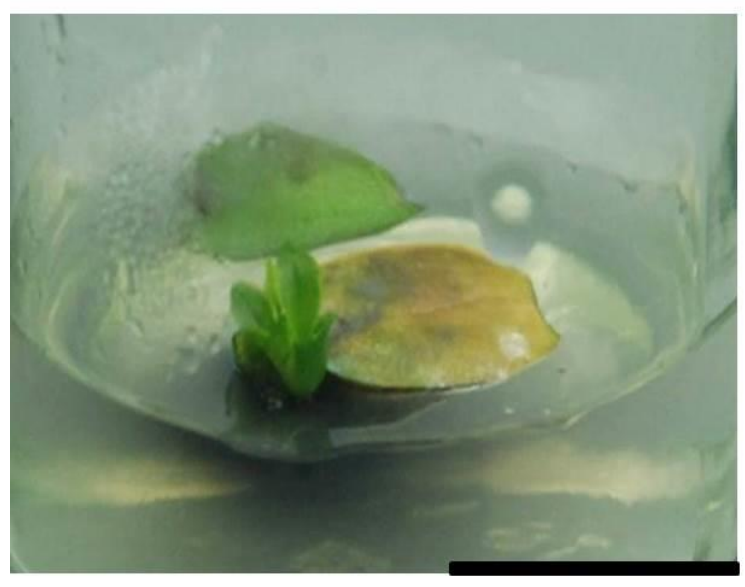

C

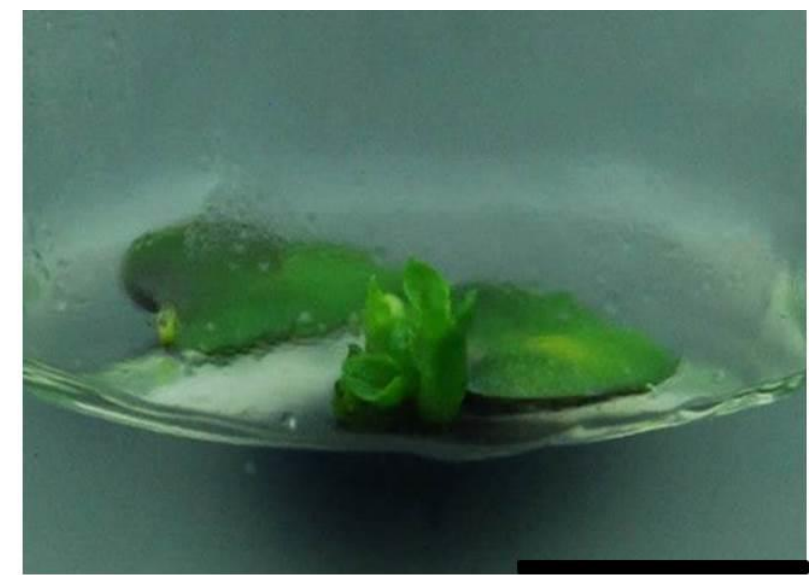

B

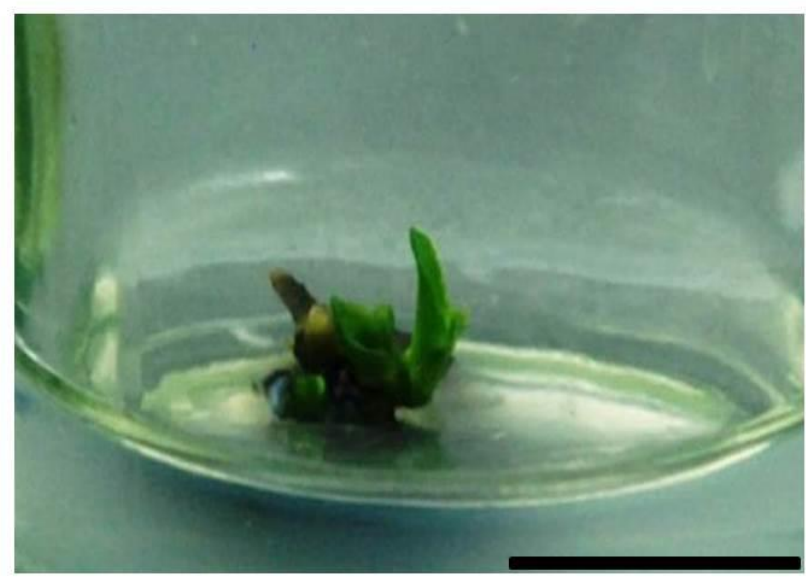

D

Figure 3: Direct shoot formation from leaf explants of the hybrid Phalaenopsis 'Pink' without callus-mediated at 0 $\mathrm{mg} \mathrm{l}^{-1} \mathrm{NAA}+2 \mathrm{mg} \mathrm{l}^{-1}$ TDZ supplemented to half-strength MS medium: A - Shoot formation after 8 weeks of culture, B - Shoot formation after 12 weeks of culture, C - Shoot formation after 16 weeks of culture, D - Shoot formation after 20 weeks of culture $($ bar $=1.0 \mathrm{~cm})$

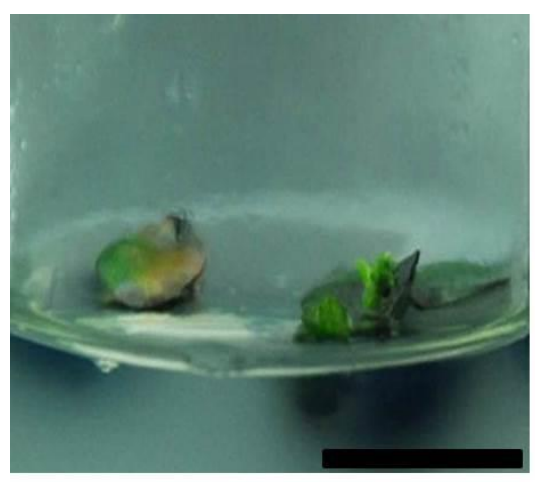

A

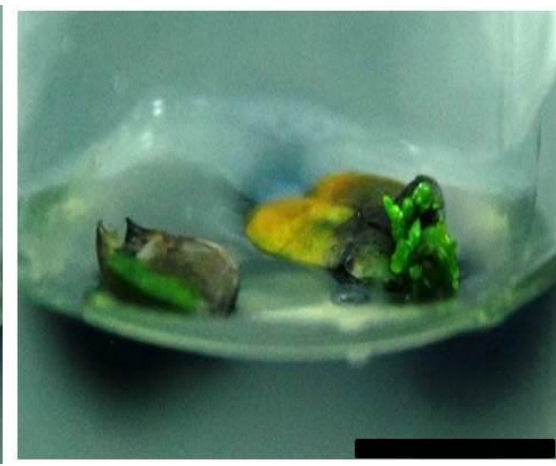

B

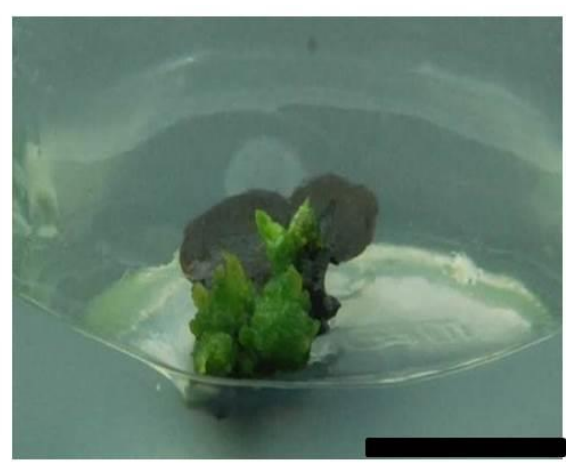

C

Figure 4: Callus regeneration from leaf explants of the hybrid Phalaenopsis 'Pink' at $0.5 \mathrm{mg} \mathrm{l}^{-1} \mathrm{NAA}+1.5 \mathrm{mg} \mathrm{I}^{-1}$ TDZ supplemented to half-strength MS medium: A - Callus formation after 12 weeks of culture, B - Callus formation after 16 weeks of culture, C - Callus formation after 20 weeks of culture $($ bar $=1.0 \mathrm{~cm})$ 


\subsection{Effects of NAA and TDZ supplemented to VW medium on the growth and direct shoot formation of leaf explants}

After five months of culture, the combination of NAA and TDZ supplemented to VW medium showed significant effect on leaf length whereas leaf width was unaffected (Table 4). Higher leaf length and percentage survival rate was obtained with higher concentrations of
NAA and TDZ. The length of leaf was found to be optimal in the combination of $0 \mathrm{mg} \mathrm{l}^{-1} \mathrm{NAA}$ and $1.5 \mathrm{mg}$ $1^{-1}$ TDZ $(2.40 \pm 0.01 \mathrm{~cm})$ with $30 \%$ survival frequency, as well as in the combination of $0.5 \mathrm{mg}^{-1} \mathrm{NAA}$ and 2 $\mathrm{mg} \mathrm{l}^{-1}$ TDZ $(2.32 \pm 0.01 \mathrm{~cm})$ with $50 \%$ survival frequency (Fig. 1d). Overall, the combination of $0.5 \mathrm{mg}$ $1^{-1} \mathrm{NAA}$ and $2 \mathrm{mg} \mathrm{l}^{-1} \mathrm{TDZ}$ supplemented to VW medium showed better performance for explant growth.

Table 4: Effects of NAA and TDZ supplemented to VW medium on leaf formation, percentage of regenerants and survival frequency of the hybrid Phalaenopsis 'Pink' leaf explants after five months of culture

\begin{tabular}{llllll}
\hline NAA & TDZ & Leaf length $(\mathrm{cm})$ & Leaf width $(\mathrm{cm})$ & Regenerants $(\%)$ & Survival frequency (\%) \\
$\left(\mathrm{mg} \mathrm{l}^{-1}\right)$ & $\left(\mathrm{mg} \mathrm{l}^{-1}\right)$ & & & \\
\hline 0 & 0 & $2.00 \pm 0.00 \mathrm{~d}$ & $1.00 \pm 0.00$ & $0.00 \pm 0.00$ & $20.00 \pm 0.14 \mathrm{c}$ \\
0 & 0.5 & $2.00 \pm 0.00 \mathrm{~d}$ & $1.00 \pm 0.00$ & $0.00 \pm 0.00$ & $20.00 \pm 0.12 \mathrm{c}$ \\
0 & 1 & $2.10 \pm 0.01 \mathrm{~cd}$ & $1.00 \pm 0.00$ & $0.00 \pm 0.00$ & $30.00 \pm 0.31 \mathrm{~b}$ \\
0 & 1.5 & $2.40 \pm 0.01 \mathrm{a}$ & $1.00 \pm 0.00$ & $0.00 \pm 0.00$ & $30.00 \pm 0.20 \mathrm{~b}$ \\
0 & 2 & $2.20 \pm 0.03 \mathrm{bc}$ & $1.00 \pm 0.00$ & $0.00 \pm 0.00$ & $30.00 \pm 0.40 \mathrm{~b}$ \\
0.5 & 0 & $2.00 \pm 0.00 \mathrm{~d}$ & $1.00 \pm 0.00$ & $0.00 \pm 0.00$ & $10.00 \pm 0.14 \mathrm{~d}$ \\
0.5 & 0.5 & $2.22 \pm 0.02 \mathrm{bc}$ & $1.00 \pm 0.00$ & $0.00 \pm 0.00$ & $30.00 \pm 0.17 \mathrm{~b}$ \\
0.5 & 1 & $2.22 \pm 0.02 \mathrm{bc}$ & $1.00 \pm 0.00$ & $0.00 \pm 0.00$ & $30.00 \pm 0.17 \mathrm{~b}$ \\
0.5 & 1.5 & $2.26 \pm 0.008 \mathrm{~b}$ & $1.00 \pm 0.00$ & $0.00 \pm 0.00$ & $50.00 \pm 0.17 \mathrm{a}$ \\
0.5 & 2 & $2.32 \pm 0.01 \mathrm{ab}$ & $1.00 \pm 0.00$ & $0.00 \pm 0.00$ & $50.00 \pm 0.10 \mathrm{a}$ \\
$F$ & & $* * *$ & $\mathrm{~ns}$ & $* * *$ \\
\hline
\end{tabular}

Data are means \pm standard error (SE) of 20 replicates. Means followed by the same letter in each column do not differ by Duncan's multiple range test at $\mathrm{p} \leq 0.05$. ns and $* * *$ indicate non-significant and significance at $\mathrm{p} \leq 0.001$.

\section{DISCUSSION}

There are various effects of PGR on embryogenesis (Koh and Loh, 2000). It has been observed that depending on the PGR composition in the culture medium, either somatic embryogenesis or organogenesis can be induced (Jimenez, 2005). The combination with appropriate concentration of NAA and BAP and the composition of macro- and microelements in the culture medium are of key importance for micropropagation of Phalaenopsis on a commercial scale, especially to stimulate shoot regeneration (Tokuhara and Mii, 1993).

In this study, the combination of $0 \mathrm{mg} \mathrm{l}^{-1} \mathrm{NAA}$ and 3 $\mathrm{mg}^{-1}$ BAP as well as $0.5 \mathrm{mg} \mathrm{l}^{-1}$ NAA and $2 \mathrm{mg} \mathrm{l}^{-1}$ BAP supplemented to half-strength MS medium resulted in $5 \%$ regenerants within 10-11 weeks of culture with $50 \%$ and $40 \%$ survival frequency, respectively. Shoots were formed directly from wounding area and continued to proliferate until 20 
weeks of culture (Fig. 2). Subculture was carried out periodically in every three weeks to prevent senescence or necrosis that might be caused by the phenolic compound released from the wounding area of the explants (Kuo et al., 2005). In this study, the growth and proliferation of plantlets were superior in the presence of higher BAP concentration compared with NAA. It has been reported that higher auxin (NAA) concentration compared with cytokinin (BAP) generally leads to root formation on the cut edge, embryogenesis and adventitious root formation whereas higher cytokinin (BAP) concentration generally leads to adventitious shoot formation, auxiliary shoot proliferation (by stimulating cell enlargement or division and growth of lateral bud) and cell cycle control (George and Sherington, 1984; Gaspar et al., 2003; Moharami et al., 2014). The combination of $0 \mathrm{mg}$ $1^{-1}$ NAA and $1 \mathrm{mg} \mathrm{l}^{-1}$ BAP supplemented to VW medium resulted in $5 \%$ regenerants where callus directly appeared from the basal region near the wounding area. It has been reported that the combination of $0.5 \mathrm{mg} \mathrm{l}^{-1} \mathrm{NAA}$ and $2 \mathrm{mg} \mathrm{l}^{-1} \mathrm{BAP}$ supplemented to modified MS medium was the most suitable combination for direct shoot formation without callus-mediated regeneration (Košir et al., 2004).

The presence of cytokinin (TDZ) was reported to play an important role in callus induction, subculture and subsequent plant regeneration of Phalaenopsis (Mok et al., 1982; Chen et al., 2000). In this study, the combination of $0.5 \mathrm{mg} \mathrm{l}^{-1} \mathrm{NAA}$ and $1.5 \mathrm{mg} \mathrm{l}^{-1} \mathrm{TDZ}$ supplemented to half-strength MS medium resulted the highest percentage $(25 \%)$ of regenerants and calluses which were formed within 11 weeks of culture with 90 $\%$ survival frequency. The combination of $0 \mathrm{mg} \mathrm{l}^{-1}$ NAA and $2 \mathrm{mg}^{-1}$ TDZ supplemented to half-strength MS medium produced the highest leaf number and leaf width with $10 \%$ of regenerants (formed after 8 weeks of culture) with $60 \%$ survival rate (Fig. 3). In Phalaenopsis, it has been reported that TDZ promoted repetitive embryogenesis from zygotic protocorms (Chen and Chang, 2004) and induced a higher frequency of regeneration from leaf explants compared with BAP and KIN, since leaf tips had a higher capacity to form embryos than other leaf regions (Chen et al., 2000; Chen and Chang, 2001; Kuo et al., 2005).

\section{CONCLUSION}

This study showed that the combination of $0 \mathrm{mg}^{-1}$ NAA and $3 \mathrm{mg} \mathrm{l}^{-1}$ BAP supplemented to half-strength MS medium was optimal for direct shoot regeneration with $5 \%$ regenerants and $50 \%$ of survival frequency. The combination of $0.5 \mathrm{mg} \mathrm{l}^{-1} \mathrm{NAA}$ and $1.5 \mathrm{mg} \mathrm{l}^{-1} \mathrm{TDZ}$ supplemented to half-strength MS medium proved to be optimal concentration in enhancing the callus formation with $25 \%$ regenerants and $90 \%$ of survival frequency. However, further research needs to be undertaken to find out the shortest time of direct shoot regeneration without callus mediated regeneration and to produce viable acclimatized plants with a high survival frequency.

\section{ACKNOWLEDGMENTS}

The authors thank the Aceh Government, Indonesia and the Asian Institute of Technology, Thailand, for providing financial assistance with a scholarship to the first author for graduate studies at the Asian Institute of
Technology, Thailand. The authors also would like to acknowledge Kasetsart University, Thailand, for providing laboratory support for the work. No potential conflict of interest was reported by the authors.

\section{REFERENCES}

Arditti J.R., Ernst. (1993). Micropropagation of Orchids. Wiley-Interscience, New York, USA.

Chen Y.C., Chang C., Chang W.C. (2000). A reliable protocol for plant regeneration from callus culture of Phalaenopsis. In Vitro Cellular \& Developmental Biology - Plant, 36, 420-423. doi:10.1007/s11627-000-0076-5

Chen J.T., Chang W.C. (2001). Effects of auxins and cytokinin on direct somatic embryogenesis from leaf explants of Oncidium 'Grower Ramsey'. Plant
Growth Regulation, 34, 229-232. doi:10.1023/A:1013304101647

Chen J.T., Chang W.C. (2004). Induction of repetitive embryogenesis from seed derived protocorms of Phalaenopsis amabilis 'Formosa Shimadzu'. In Vitro Cellular \& Developmental Biology - Plant, 40, 209-293. doi:10.1079/IVP2003527

Gaspar T.H., Kevers C., Faivre-rampant O., Crevecoeur M., Penel C., Greppin H., Dommes J. (2003). Changing concepts in plant hormones action. In 
Vitro Cellular \& Developmental Biology - Plant, 39, 85-106. doi:10.1079/IVP2002393

George F.E., Sherrington P.D. (1984). Plant Propagation by Tissue Culture: Handbook and directory of commercial laboratories. Exegetics Ltd., Edington, England, UK, 1984. pp. 709.

Ishii Y., Takamura T., Goi M., Tanaka M. (1998). Callus induction and somatic embryogenesis of Phalaenopsis. Plant Cell Reports, 17, 446-450. doi: $10.1007 / \mathrm{s} 002990050423$

Jimenez V.M. (2005). Involvement of plant hormones and plant growth regulators on in vitro somatic embryogenesis. Plant Growth Regulation, 47, 91110. doi:10.1007/s10725-005-3478-X

Košir P., Škof S., Luthar Z. (2004). Direct shoot regeneration from nodes of Phalaenopsis orchids. Acta Agriculturae Slovenica, 83, 233-242.

Koh W.L., Loh C.S. (2000). Direct somatic embryogenesis, plant regeneration and in vitro flowering in rapid cycling Brassica napus. Plant Cell Reports, 19, 1177-1183. doi: $10.1007 / \mathrm{s} 002990000268$

Kuo H.L., Chen J.T., Chang W.C. (2005). Efficient plant regeneration through direct somatic embryogenesis from leaf explants of Phalaenopsis 'Little Steve'. In Vitro Cellular \& Developmental Biology - Plant, 41, 453-456. doi:10.1079/IVP2005644

Lu C.Y. (1993). The use of thidiazuron in tissue culture. In Vitro Cellular \& Developmental Biology - Plant, 29, 92-96. doi:10.1007/BF02632259

Moharami L., Hosseini B., Ravandi E.G., Jafari M. (2014). Effects of plant growth regulators and explant types on in vitro direct plant regeneration of Agastache foeniculum, an important medicinal plant. In Vitro Cellular \& Developmental Biology Plant, 50, 707-711. doi:10.1007/s11627-014-96402

Mok M.C., Mok D.W.S., Armstrong D.J., Shudo K., Isogai Y., Okamoto T. (1982). Cytokinin activity of
N-Phenyl-N'- (1,2,3-thidiazuron-5-yl) urea (thidiazuron). Phytochemistry, 21, 1509-1511. doi:10.1016/S0031-9422(82)85007-3

Murashige T., Skoog F. (1962). A revised medium for rapid growth and bioassays with tobacco tissue culture. Physiologia Plantarum, 15, 473-497. doi:10.1111/j.1399-3054.1962.tb08052.x

Niknejad A., Kadir M.A., Kadzimin B.S. (2011). In vitro plant regeneration from protocorms-like bodies (PLBs) and callus of Phalaenopsis gigantea (Epidendroidaceae: Orchidaceae). African Journal of Biotechnology, 10, 11808-11816.

Park S.Y., Murthy H.N., Paek K.Y. (2001). Rapid propagation of Phalaenopsis from floral stalkderived leaves. In Vitro Cellular \& Developmental Biology-Plant, 38, 162-172.

Purohit S.S. (2005). Plant tissue culture. Student Edition, Singapore. pp. 100-125.

Teob E.S. (1989). Orchid of Asia. Times Books International, Singapore.

Tokuhara K., Mii M. (1993). Micropropagation of Phalaenopsis and Doritaenopsis by culturing shoot tips of flower stalk buds. Plant Cell Reports, 13, 711. doi:10.1007/BF00232306

Tokuhara K., Mii M. (2001). Induction of embryonic callus and cell suspension culture from shoot tips excised from flower stalk Buds of Phalaenopsis (Orchidaceae). In Vitro Cellular \& Developmental Biology - Plant, 37, 457-461. doi:10.1007/s11627001-0080-4

Vacin E., Went F.W. (1949). Some pH changes in nutrient solutions. Botanical Gazette, 110, 605613. doi:10.1086/335561

Zahara M., Datta A., Boonkorkaew P. (2016). Effects of sucrose, carrot juice and culture media on growth and net $\mathrm{CO}_{2}$ exchange rate in Phalaenopsis hybrid 'Pink'. Scientia Horticulturae, 205, 17-24. doi:10.1016/j.scienta.2016.04.011 